УДК 327

DOI dx.doi.org/10.30970/vir.2018.45.0.9452

\title{
CSDP-UKRAINE RELATIONS IN THE FACE OF THE CONFLICT THE EXPERIENCE AND PERSPECTIVES
}

\author{
Andrzej Demkowicz \\ The Tadeusz Kościuszko Military University of Land Forces, \\ 109, Czajkowskiego Str., Wroclaw, Poland, 51-147, tel. +48-71-2616581 10, \\ email: andrzej.demkowicz@awl.edu.pl
}

Ukraine has been an important partner for the European Union in the eastern part of Europe, especially in the post-Soviet security area. The European Union has been implementing not only the political and economic, but also the security integration with Ukraine by the Common Security and Defence Policy (CSDP). The aim of the article is to present the relationship in the sphere of security and defense between the European Union and Ukraine, particularly, in the face of the greatest challenge to the stability and security of the European continent in the 21 st century. The author used the combined research methods to analyze the content and decisions and sources as well as the observation of current processes in the area of security in Ukraine.

The author's main goal is to focus on the relations between the European Union and Ukraine in the area of security and defence, especially, in managing during the political and military crisis 2013-2015. The conflict in Ukraine, which we have witnessed, has a several phases. The reaction of the European Union in each phase of the conflict was adequate to the situation and consistent and was also adequate to the permissions in the area of the Common Security and Defence Policy (CSDP). The European Union, in its sense of responsibility for shaping security at its borders, should have reacted adequately to circumstances. The author have attempted to describe the relations, the process of their shaping and practical implementation by the involvement of the European Union in the conflict in the Eastern part of Ukraine.

The practical outcome of the reaction of the European community to the events in the eastern Ukraine consisted primarily in the establishing and organizing of an OSCE monitoring mission and the European Union Advisory Mission for Ukraine (EUAM) in this region. The decision to establish it was meant to be a clear signal of Russia regarding the EU's position on supporting Ukraine's stability, independence and integrity. The advisory mission gives the EU the opportunity to be at the crisis area, as well as to promote the declar's values and, most importantly, to improve its image in the international environment, but it is hard to be perceived as a success of the CSDP. However, we cannot ignore influence on the development of the situation. A comparison of EU actions with NATO activities illustrates the capabilities of the Member States regarding the role and potential of both organizations. However, it was not possible to discuss military-type issues at the EU summits because of the fundamental differences between these two organizations. Based on the current CSDP implementation practice, that the importance of the EU in solving military conflicts is systematically decreasing. The real task of CSDP is to manage crises and conflicts of low intensity of military operations in peripheral countries (mainly African), and above all, post-conflict reconstruction of civilian security systems. If the European Union intends to play a key role in the management of military crises, the first and main objective of its operation should be to effectively ensure the survival and consolidation of vulnerable states, and in the second stage to shape high standards of state management.

The main task of government administration in Ukraine is to achieve effectiveness in law enforcement and to achieve a high level of efficiency and in the functioning of bodies responsible for internal security and defence.

(C) Demkowicz Andrzej, 2018 
The countries which aspire to enter the Western European political system in a credible way to change its current model of functioning, which is not always in line with the democratic one and a transparent model of the European Union Member States. And the EU can help in this by CSDP. The potential loss of Russia's influence in the Black Sea region has stimulated its efforts to shape all areas of strategic security policy in the region. The operational cooperation with the EU should be continued by initiatives such as the EU Combat Groups as this is an important element that will contribute to a more complete integration with the EU, and even with NATO in the future. the basic condition of maintaining the stability of the region is the consistent and common way of acting of EU member states in relations with the Russian Federation.

Thus, the way for the effectiveness of the European Union is its unconditional unity in conducting foreign policy, especially in sensitive area of security.

Key words: The European Union; Ukraine; military crisis; CSDP.

Since its independence, Ukraine has been an important partner for the European Union in the eastern part of Europe, especially in the post-Soviet security area [1]. The European Union has been implementing the political association with Ukraine and the economic integration with the EU Member States through the European Neighbourhood Policy and the Eastern Partnership.

The European Union was making the efforts to support Ukraine in stopping the hybrid aggression in its eastern areas, thus maintaining the territorial integrity and the real independence of the Ukrainian state. The EU's efforts has been trying to combine pressure through restrictive measures with diplomatic efforts and urge to dialogue.

The history of Ukraine's contacts with the European Union is almost 30 years old. It has lasted since the signing of «The Partnership and Cooperation Agreement between the European Communities and their Member States, and Ukraine» on 14 June 1994, which entered into force in 1998 and expired in 2008 and was the basis for the cooperation and reforms [2]. In 1998, the first meeting of the Cooperation Council between Ukraine and the EU was organized, during which representatives of Ukraine officially declared their accession to the status of an associated country with the EU [3,p.68].

Another important occurrence in the European Union-Ukraine relations was the adoption of the EU in the EU Common Strategy towards Ukraine on 11 December 1999 during the EU Summit in Helsinki of and its extension until December 2004 [4]. This document, as one of the main objectives of cooperation, declared jointly facing threats to stability and security in Europe, environmental protection, energy and nuclear safety [5, p. 17]. Then a number of sectoral documents was signed, including also covering security issues [6, p. 63-64].

In 2003 during the Ukraine-European Union Summit, it was decided to launch the consultations in order to start the Wider Europe Action Plan for Ukraine, which included, inter alia, issues of nuclear safety, the fight against terrorism and organized crime $[5$, p. 20].

A special clasp closing the period of many years of contacts and negotiations, as well as Ukraine's efforts was signing, until June 27, 2014, the economic part of The Ukraine-European Union Association Agreement, which was approved by The Verkhovna Rada of Ukraine on 16 September 2014 and it was signed by the president [7]. 
However, this important final was preceded by the events that radically changed the perception of the situation of their country by Ukrainian citizens, as well as the attitude of neighbours and existing partners to the Ukraine's role and its position in Europe. The crisis situation, which was created after the attempt to suppress proEuropean demonstrations on 31 November 2013 in Kiev and its further escalation, by using the violence by the government's security forces, resulted in the action of representatives and organs of the European Union responsible for conducting security policy to eliminate the negative effects as the outcome of these dynamic events. The European Union's involved in order to support demonstrators in their pursuit of implementing European values that were at risk as the President of Ukraine urged to withdraw from talks about the Association Agreement and which may have prevented the escalation of violence in a potential internal conflict and security destabilization in the immediate vicinity of the EU border. The lack of EU involvement would result in the loss of the image of an effective arbitrator who is able to effectively manage the conflict near its borders. The failure of EU efforts in this matter would call into question The Common European Foreign and Security Policy as the European Union's tool in ensuring its status as a «superpower», at least at a regional position.

By its representatives, the European Union has repeatedly called on adversaries of the conflict to refrain from using force and recommended political dialogue in possible cooperation with regional security organizations $[8$, p. 2]. During the pro-European demonstrations from November 2013 to February 2014, the representatives of the European Union appealed several times and visited Ukraine. The President of the European Council, Herman van Rompuy, High Representative for Foreign Affairs and Security Policy Catherine Ashton and the President of the European Commission Jose Manuel Barroso, personally engaged in the political dialogue and warned against the use of violence. In December 2013, C. Ashton visited Kiev, during which she met with the president W. Yanukovych, as well as with the demonstrators on the streets of Kiev.

However, in the face of the use of the firearms and the deaths of the demonstrators caused by the government police, the efforts of the representatives and bodies of the European Union proved to be ineffective. As a result of the escalating internal conflict, the Council of the European Union decided to impose the sanctions on the policy makers and the political entities responsible for or contributing to the use of violence and violations of the basic human rights during the conflict in Kiev. The sanctions were especially directed to the government administration, and in particular to the president, who was directly responsible for the state of internal security $[9$, p. $1-$ 2]. It seems that the visit of foreign ministers of France, Germany and Poland, which took place on 18-19 February 2014, at the request of the High Representative Foreign Affairs and Security Policy p. Catherine Ashton, somehow contributed to the resignation and defeat of President V. Yanukovich [10, p. 47].

The escape of President Yanukovich marked the political changes and the beginning of the fiasco of the policy of the Russian Federation (FR) in Ukraine. At the same time, it caused the implementation of a scenario of the hybrid aggression by the administration of the Russian Federation. The Russian intervention was carried out 
according to earlier planned and prepared model that caused a threat to the sovereignty, the independence and the territorial integrity of Ukraine [11, p. 16].

The implementation of the Russian scenario for Ukraine began on 26 February 2014 by use of military groups of unknown origin, that began to occupy and block the strategic and operational facilities in the Crimea. However, in reality, these were the demonstration actions of regular troops and special forces of the Russian Federation operating as local paramilitary groups. In the face of an act of aggression that is incompatible with the United Nations Charter, the OSCE Final Act, the 1994 Budapest Memorandum and the Bilateral Agreement on Friendship, Cooperation and Partnership of 1997, the Council of the European Union condemned the activities of the Russian Federation and called to withdraw its troops from the territory of Ukraine and commence operations in accordance with international law to resolve the conflict [12, p. 104-110].

At the same time, the Council called for transparent and democratic activities of the new Ukrainian authorities in order to stabilize the security situation and to maintain the democratic principles in state reforms [13, p. 1-2]. Further reaction of the EU Council, in the face of continuous actions of the Russian Federation in Ukraine, was freezing of foreign assets in order to prevent a takeover by separatist authorities or persons, who were responsible for undertaking undemocratic activities in the Crimea [14, p. 1]. The activities of the EU Council were strengthened by the position of the European Council condemning the activities of the Russian Federation in Ukraine and the announcement of the suspension of the relations in significant areas of cooperation [15, p. 1-2]. On the basis of the total military domination and the intimidation of local communities and after the illegal referendum on 16 March 2014, the Russian Federation took over the power and decided to secede the occupied territory from Ukraine [16, p. 134].

The EU Council's response was to deepen the sanctions and condemn the illegal referendum in Crimea, which violated the Ukrainian constitution [17, p. 1-2]. However, the visa and financial sanctions, which were being extended by the EU within the next few months, the freezing of foreign assets to prevent an illegal takeover by the separatist authorities and representatives from the previous administration did not change the nature of this conflict. The main reason for this situation was low coverage and the lack of a significant impact on the Russian economy and the possibility of Russia is pursuing a further armed confrontation.

In addition, this kind of reaction was calculeted by the Russian decision-makers in the political and economic costs of this long-planned hybrid aggression, which could be implemented in post-Soviet countries.

The next stage of the Russian Federation's aggression towards Ukraine was the destabilization of its eastern part, also largely dominated by the Russian-speaking population [18, p. 204-208]. The local forces of the separatists, the influx of «volunteers» and subunits composed of soldiers of regular military forces of the Russian Federation carried out the full-scale combat operation using modern and advanced military equipment [19] whose ownership in the first days of fighting was hidden so that Russian federation shouldn't be seen as the participant of fighting in the 
international armed conflict [20, p. 356]. The location of the large number of Russian troops close to the eastern border, the large number of the military exercises in the immediate vicinity of the Ukrainian-Russian border, as well as indirect and often direct support of the separatist party in the ongoing struggle in eastern Ukraine determined the limited actions of the Armed Forces of Ukraine and led to the failure of the Ukrainian anti-terrorist operation in 2014 [21].

The attempts to solve the problem of hybrid aggression by using by Ukraine the military tools in the eastern part of the Donbass region and despite the initial success, which resulted in the restoration of Ukrainian government power in the most part of the territory, ended with the failure.

The symbol of this failure was the calamity in the «Ilovaisk Encirclement» and its tragic consequences for the Ukrainian forces [22].

The hitherto used tools of political pressure implemented by the EU bodies did not result in the intended effect and were ignored by the separatist side, who were motivated in this area by the Russian Federation [23]. It is worth noting that even then the EU activities were inherently reactive in character but at the same time they were late in relation to the reactions of the American and Canadian administrations.

As part of the activities of European powers, it should be noted that Waimar Triangle played an important role at the time. The peace talks, in which Germany and France participated, revealed the position of the EU Member States.

The Russian side wanted to talk only with the selected partners. The effectiveness of Russian's efforts was manifested in the creation of the so-called the «Normandy Formula» of the meetings, which resulted in signing the protocol in Minsk 2014 and the armistice agreement in the following year [24]. This representation of Western Europe chosen by the Russian administration showed the place and the role of the EU bodies in the foreign policy of the Russian Federation and the attitude of its diplomacy to the CFSP.

In Europe, an intensive debate was held on the practical and the effective ways of involving the EU institutions in the ongoing armed conflict in order to only not to monitor its course, but in the future, conduct operation of the separation and control of a ceasefire [25]. The possibility of using armed forces as part of a possible European Union mission seemed illusory [26]. Mostly, the issues of the counteracting the negative effects of Russian propaganda on Western European societies and their elites were focused on. The mass media, as a tool for hybrid activities, could significantly distort the real picture of the war in Ukraine [27, p. 215-231].

The practical outcome of the reaction of the European community to the events in the eastern Ukraine consisted primarily in the establishing and organizing of an OSCE monitoring mission in this region [28].

The OSCE mission does not seem to fulfill the tasks and objectives imposed on it in the maximum way, but at the same time it must be admitted that it operates under complex political conditions and under the pressure of Russian actions, which has been destabilizing its effectiveness. The ineffectiveness of the OSCE mission activities has been repeatedly emphasized by the mass media and decision makers of the international community. For this reason, it was decided to strengthen the activities 
of the European community through the announcement of sending to the Ukraine a mission under the Common Security and Defence Policy (CSDP), which was discussed at the informal meeting of EU diplomats [29].

In the first place, the task of the new mission was not only to support the activities of the observation mission of the Organization for Security and Co-operation in Europe (OSCE), but also to modify the nature of the European Union's involvement in the ongoing conflict. In the area of the responsibility of the mission issues related to the reform of the judiciary and the police were included, in order to ensure stability of the government and the restoration of public confidence of Ukrainians to public security organs, weakened by the corruption and the misuse. On 22 July 2014, according to the decision of the Council of the European Union (No. 2014/486/ CSFP), the European Union Advisory Mission for Ukraine (EUAM) was set up under the mechanism of the Common Security and Defence Policy of the European Union [30]. Officially, the EU mission in Ukraine began its operation on 1 December 2014 with the goal of helping the Ukrainian government and self-government administration in the security sector reform.

The main task of the EUAM mission is the reconstruction of state public security organs and the improvement of the operation of Ukrainian courts and the prosecutor's office. The strategic goal of the reform is to restore the trust of Ukrainian citizens to civil security authorities. But above all, creating a strong state that will be able to resist the tools and methods of hybrid aggression. The activities of the EUAM mission in Ukraine consist in the strategic consultancy in the reconstruction of civil security organs, the consultancy at the operational level, as well as conducting training activities, the implementation of the projects and the cooperation and the coordination of the undertaken reforms and actions between the Ukrainian side and the international organizations.

Primarily, the priorities which were set for the mission are the separation of functions and tasks between authorities to avoid duplication of competences and the accomplishment of the partnership in relations with the Ukrainian society.

At the same time, there are strives to guarantee the right to the freedom of assembly and functioning of the security services in this area in accordance with the European standards and with the respect for human rights. Strengthening and supporting the capabilities of security organs in conducting criminal cases, including in particular those related to corruption crimes, have been given priority [31].

\section{CONCLUSIONS}

The above mission is a test of the capabilities of European Union bodies in resolving conflicts that arise at its borders, and in particular in its immediate neighborhood in Europe. Its character indicates a model involvement of this European organization in resolving crises. This is complementary to current global or regional powers. According to the Lisbon Treaty, CSDP missions are a post-crisis tools, but the EUAM mission was established during the ongoing crisis, which is rather unique in the current practice of setting up the crisis management missions by the European Union. The decision to establish it was meant to be a clear signal of Russia regarding 
the EU's position on supporting Ukraine's stability, independence and integrity. For Russia it was a sign that the EU is ready to get involved in the dispute.

The European Union established advisory rather than military counsel mainly due to the fact that the international community, especially in Central and Eastern Europe, expected it to react and show responsibility for Ukraine, and at the same time this form was relatively acceptable and not irritating Russia in relation to the military form of the mission. The advisory mission gives the EU the opportunity to be at the crisis area, as well as to promote the declar's values and, most importantly, to improve its image in the international environment.

The reaction of the European Union to the Russo-Ukrainian conflict, taking into account its course and hitherto effects, is hard to be perceived as a success of CFSP. However, we can't ignore influence on the development of the situation.

It is important to limit the activities of the European institutions as the conflict escalates.

A comparison of EU actions with NATO activities illustrates the capabilities of the Member States regarding the role and potential of both organizations. However, it was not possible to discuss military-type issues at the EU summits because of the fundamental differences between these two organizations.

It seems based on the current CSDP implementation practice, that the importance of the EU in solving military conflicts is systematically decreasing.

The experience of EU involvement in the conflict in Ukraine confirms its complementary role in crisis management in Europe and in the world, as it was in Iraq and Afghanistan.

The real task of CSDP is to manage crises and conflicts of low intensity of military operations in peripheral countries (mainly African), and above all, post-conflict reconstruction of civilian security systems. Actual military advice and training in Ukraine has been taken by the states such as the US or Canada, which can afford such an unambiguous attitude towards Russia. However, it should be remembered that the European Union can improve capabilities and support reforms, but EU will not guarantee the defence of the territory. Especially, this will not be guaranteed by NATO to a country not being a member of the North Atlantic Alliance.

The European Union should increase its involvement in shaping security in the countries, in which it intends to engage politically and economically in the future. If the European Union intends to play a key role in the management of military crises, the first and main objective of its operation should be to effectively ensure the survival and consolidation of vulnerable states, and in the second stage to shape high standards of state management.

The main task of government administration in Ukraine is to achieve effectiveness in law enforcement and to achieve a high level of efficiency and in the functioning of bodies responsible for internal security and defence against external military threats [32].

Currently, the countries in a situation similar to Ukraine need support in the protection of external borders in a military style, and in the long term, ensuring 
Andrzej Demkowicz

standards of internal security services in the style of Western European countries. Ukraine is an example for countries in the so-called gray security zone.

The countries which aspire to enter the Western European political system in a credible way to change its current model of functioning, which is not always in line with the democratic one and a transparent model of the European Union Member States. And the EU can help in this by CSDP.

Under the rule of President Yanukovich and his predecessors, the Ukrainian government administrations declared Ukraine's neutrality and maintained the status of an out-of-block state.

However, as for as the current events are concerned, it can be stated that it was this kind of policy that made Ukraine a victim of Russian aggression.

At present, it can be assessed that there are the following directions of building Ukraine's external security:

1.Taking an official or unofficial course for its future membership in NATO as a real guarantor of independence.

2. Achieving the compatibility of armed forces with NATO standards resulting in the creation of the possibility of immediate military support by the Alliance-in the adverse development of the situation. But at the same time, staying neutral with its announcement or without announcing this fact.

It should be remembered that there is no possibility for Ukraine to join NATO in the closest possible perspective. The main or perhaps the only reason is the unregulated conflict in its eastern part. And this has been one of the fundamental determinants of Russia's policy at its borders.

The potential loss of Russia's influence in the Black Sea region has stimulated its efforts to shape all areas of strategic security policy in the region. Ukraine has positive experience in international military cooperation with NATO, the EU or with the V4 states (EU Border mission in Ukraine and in the Ukrainian participation in Operation Ocean Shield, EUNAVFOR, Stabilization Mission in Iraq) which in the past resulted in political approchement, but above all in the acquisition of practical knowledge in cooperation with NATO and EU forces. Cooperation under the CSDP can be carried out through:

In civil security aspects:

1. stabilizing security along the borders;

2. financial support for projects improving the civil security aspects;

3. technical consultancy on security sector reforms;

4. implementation of high technologies in the area of security;

5. support for securing terrestrial, air and sea communication infrastructure. In the military aspects of security:

1. supporting the defense planning process;

2. reform of the military resources management model;

3. cooperation of defence industries (eg satellite positioning system, space technologies, aerospace industry). 
The operational cooperation with the EU should be continued by initiatives such as the EU Combat Groups as this is an important element that will contribute to a more complete integration with the EU, and even with NATO in the future.

As for assessing the involvement of European Union bodies in solving the conflict in Ukraine in the area of such a sensitive area of security, EU internal conditions should be taken into account.

We should remember about the limitations in the functioning of this organization

in an international environment as a collection of sovereign states. The European Union in its activities must be based on consensus and take into account the diversity of national Member States' interests. At the same time, taking action on the international arena, the EU and its members should credit the declared and promoted universal values. An idealistic approach to many issues of relations between states and nations, however, is verified in the face of the pragmatics of shaping international relations. In cases of crises and conflicts in Central and Eastern Europe, the interests and policies Russian Federation should be taken into consideration as it is the state which seldom takes into account or treats instrumentally direct contacts with the bodies of international organizations. Russian policy makers prefer bilateral relations, especially with partners who are influential in European organizations because of their political, economic or military potential. Such policy means that the effectiveness of the international organization's bodies will be at a low symbolic level.

Therefore, the basic condition of maintaining the stability of the region is the consistent and common way of acting of EU member states in relations with the Russian Federation.

Thus, the way for the effectiveness of the European Union is its unconditional unity in conducting foreign policy, especially in sensitive area of security.

\section{REFERENCES}

1. Foreign and security policy [access on 15 April 2018] http://ukraine-eu.mfa.gov.ua/en/ukraineeu/dialogue/foreign-policy.

2. Partnership and Cooperation Agreement between the European Communities and their Member States, and Ukraine [access on 15 April 2018] http://ec.europa.eu/world/agreements/prepareCreate TreatiesWorkspace/treatiesGeneralData.do?step=0\&redirect=true\&treatyId=217; Partnership $\quad$ and Cooperation Agreements (PCAs): Russia, Eastern Europe, the Southern Caucasus and Central Asia [access on 15 April 2018] http://eur-lex.europa.eu/legal-content/EN/TXT.

3. Jasiński $F$. Rola sprawiedliwości i spraw wewnętrznych w ramach wschodniego wymiaru Unii Europejskiej: brak zaufania czy brak koncepcji? In «Nowe sąsiedztwo» na wschodzie poszerzonej Unii, ed. Kołodziej T., Elipsa, Warszawa 2005, p. 68.

4. EUROPEAN COUNCIL COMMON STRATEGY of 11 December 1999 on Ukraine (1999/877/CFSP) [access on 20 April 2018] https://www.consilium.europa.eu/uedocs.

5. Szerzej zob. Kołodziej T., «Nowe sąsiedztwo» na wschodzie poszerzonej Unii Europejskiej: wyzwania dla PECSA, «Nowe sąsiedztwo»,op. cit., p.17.

6. Zob. szerz. Bąba W., Zając M., «Stosunki zewnętrzne Unii Europejskiej z Ukrainą, Białorusią i Rosją», Zeszyty Naukowe Akademii Ekonomicznej w Krakowie, no 734, 2006, p. 63-64.

7. Ukraine ratifies EU integration deal [access on 19 April 2018] www.theguardian.com/world/ 2014/sep/16/ukraine-ratifies-eu-integration-deal-autonomy-eastern-regions.

8. Council conclusions on Ukraine, Foreign Affairs council meeting Brussels, 10 February 2014, p. 2 [access on 20 April 2018] http://www.consilium.europa.eu. 
Andrzej Demkowicz

9. Council conclusions on Ukraine, Foreign Affairs council meeting Brussels, 20 February 2014, s. 12 [access on 20 April 2018] http://www.consilium.europa.eu.

10. Sobczyk K. Konflikt na Ukrainie - porażka czy szansa dla Wspólnej Polityki Bezpieczeństwa i Obrony UE?, «Bezpieczeństwo Narodowe», 2015, no 1, s. 47.

11. Wojnowski M., Koncepcja «wojny nowej generacji» w ujęciu strategów Sztabu Generalnego Sił Zbrojnych Federacji Rosyjskiej, «Przegląd Bezpieczeństwa Wewnętrznego», 2015, no 13, p. 16.

12. Ochman P., Wojas J., Zagadnienia prawne rosyjskiej interwencji zbrojnej na Krymie w 2014 r., Sprawy Międzynarodowe, 2016, no 1, p. 104-110.

13. Council conclusions on Ukraine, Foreign Affairs council meeting, Brussels, 03 March 2014, s. 12 [access on 16 April 2018] http://www.consilium.europa.eu.

14. EU freezes misappropriated Ukrainian state founds, Brussels, 5 March 2014, p. 1 [access on 20 April 2018] http://www.consilium.europa.eu.

15. Statement of the Heads of State or Government on Ukraine, European Council, Brussels, 06 March 2014, s. 1-2 [access on 20 April 2018] http://www.consilium.europa.eu.

16. Szpak A., Status „małych zielonych ludzików” w konflikcie zbrojnym na Ukrainie, «Stosunki Międzynarodowe»,2016, $\mathrm{nr} 3$, s.134.

17. EU adopts restrictive measures against actions threatening Ukraine's territorial integrity, Council of the European Union, Brussels, 17 March 2014, p. 1-2 [access on 16 April 2018]. $\mathrm{http} / /$ www.consilium.europa.eu; EU strengthens sanctions against actions undermining Ukraine's territorial integrity, Council of the European Union, Brussels, 21 March 2014, p. 1-2 [access on 20 April 2018] http://www.consilium.europa.eu.

18. Bryjka F., Rosyjska wojna zastępcza w Donbasie, «Ante Portas - Studia nad Bezpieczeństwem», 2016, no. 1(6), p. 204-208.

19. Ferguson J., Jenzen-Jones N. R. Raising Red Flags: An Examination of Arms \& Munitions in the Ongoing Conflict in Ukraine, ARES Armament Research Services, Research Report no. 3 [access on 20 April 2018] www.armamentresearch.com; Servicemen of the Russian Armed Forces who takes part in combat actions in Ukraine [access on 21 April 2018]. http://gur-mou.gov.ua/en/content/russiacambatants-suspected-of-committing-war-crimes.html.

20. Heinsch $R$. Conflikct classification in Ukraine: The return of the «proxy war»?, «International Law Studies», 2015, no 91, p. 356.

21. Freedman L. Ukraine and the Art of Limited War, «Survival» [access on 21 April 2018]. https://www.iiss.org/-/media//silos/survival/2014/survival--global-politics-and-strategy-december-2014january-2015/56-6-02-freedman/56-6-02-freedman.pdf.

22. Міноборони оприлюднило повний звіт про «Іловайський котел» [ access on 21 April 2018] http://www.depo.ua/ukr/politics/u-minoboroni-opublikuvali-povniy-zvit-pro-ilovayskiy19102015131400

23. EU-Ukraine relations, «Fact Sheet», Brussels, 24 April 2015, no 150424/05 [access on 20 April 2018]. http://www.consilium.europa.eu.

24. PROTOCOL on the results of consultations of the Trilateral Contact Group (Minsk, 05/09/2014) [access on 10 maj 2018]. http://mfa.gov.ua/en/news-feeds/foreign-offices-news/27596-protocolon-theresults-of-consultations-of-the-trilateral-contact-group-minsk-05092014; Minsk Agreement: Ukraine peace deal terms in English [access on 10 maja 2018]. Dostepny w World Wide Web: http://uatoday.tv/ news/minsk-memorandum-in-english-unofficial-translation-of-ukraine-peace-deal-408912.html.

25. Gotev G. Yelisieiev: The EU should send a CSDP mission to Ukraine, [access on 10 may 2018] https://www.euractiv.com/section/europe-s-east/interview/yelisieiev-the-eu-should-send-a-csdp-missionto-ukraine.

26. Holmov N., A test too far for the EU CSDP? - Peacekeepers to the Donbas, 20 March 2015 Ukraine [access on 10 may 2018]. http://www.odessatalk.com/2015/03/a-test-too-far-for-the-eu-csdppeacekeepers-to-the-donbas.

27. Wasiuta O., Wasiuta S. Wojna hybrydowa Rosji przeciwko Ukrainie, Arkana 2017, p. 215-231.

28. Decision No. 1117 Deployment of an OSCE Special Monitoring Mission to Ukraine [access on 10 may 2018]. http://www.osce.org/pc/116747?download=true.

29. Nieformalne spotkanie ministrów obrony państw UE [access on 28 may 2018] http://m.mon.gov.pl/aktualnosci/artykul/2014-09-09-nieformalne-spotkanie-ministrow-obrony-UE/. 
30. COUNCIL DECISION 2014/486/CFSP of 22 July 2014 on the European Union Advisory Mission for Civilian Security Sector Reform Ukraine (EUAM Ukraine) Ukraine [access on 10 maj 2018]. http://eur-lex.europa.eu/legal . http://www.euam-ukraine.eu/en/what-we-do/our-priorities.

31. http://www.euam-ukraine.eu/en/what-we-do/our-priorities [access on 10 may 2018].

32. Popescu N. First lessons from the Ukrainian crisis, "Alert», 10 October 2014 No 41, Ukraine [access on 10 may 2018] Web:http://www.iss.europa.eu/publications/detail/article/first-lessons-from-theukrainian-crisis.

Стаття надійшла до редколегії 10.06.2018

Прийнята до друку 01.09.2018

\title{
ВІДНОСИНИ СПБУ-УКРАЇНИ В УМОВАХ КОНФЛІКТУ: ДОСВІД ТА ПЕРСПЕКТИВИ
}

\author{
Анджей Демковіч \\ Університет сухопутних військ імені Т. Костюшка, \\ вул. Чайковського, 109, м. Вроилав, Польща, 51-147, тел. +48-71-2616581 10, \\ email: andrzej.demkowicz@awl.edu.pl
}

Україна була важливим партнером для Європейського Союзу у східній частині Європи, особливо на пострадянському безпековому просторі. Європейський Союз реалізує не тільки політичну та економічну, але й безпекову інтеграцію з Україною в рамках Спільної політики безпеки та оборони (СПБО). Метою статті є аналіз відносин у сфері безпеки та оборони між Європейським Союзом та Україною, зокрема, в умовах найбільшого виклику для стабільності та безпеки європейського континенту у XXI столітті. Автор використовував комбіновані методи дослідження для аналізу змісту та рішень, джерел, а також спостереження за поточними процесами в галузі безпеки в Україні.

Основна мета автора полягає в тому, щоб зосередитися на відносинах між Європейським Союзом та Україною у сфері безпеки та оборони, зокрема, під час політичної та військової кризи 2013-2015 років. Конфлікт в Україні, який ми бачили, має кілька етапів. Реакція Європейського Союзу на кожному етапі конфлікту була адекватною ситуації та послідовною, а також адекватною дозволам у сфері Спільної політики безпеки і оборони. Європейський Союз, у своєму розумінні відповідальності за формування безпеки на своїх кордонах, повинен був адекватно реагувати на обставини. Автор спробував описати відносини, процес формування та практичну реалізацію за участю Європейського Союзу в конфлікті у східній частині України.

Практичний результат реакції європейської спільноти на події на сході України полягав, в першу чергу, у створенні та організації моніторингової місії ОБСЄ та Консультативної місії Європейського Союзу в Україні (EUAM) у цьому регіоні. Рішення про іiі заснування було чітким сигналом Росії щодо позиції СС з підтримки стабільності, незалежності та цілісності України. Консультативна місія надає ЄС можливість бути в кризовій сфері, а також сприяти цінностям декларації і, головне, покращити свій імідж в міжнародному середовищі.

Порівняння дій ЄС 3 діяльністю НАТО ілюструє можливості держав-членів щодо ролі та потенціалу обох організацій. Проте на самітах ЄС неможливо обговорити питання військового типу через фундаментальні відмінності між цими двома організаціями. Важливість ЄС у вирішенні військових конфліктів систематично зменшується. Реальне завдання СПБО полягає в управлінні кризами та конфліктами низької інтенсивності військових операцій в периферійних країнах (в основному африканських) i, перш за все, постконфліктної реконструкції цивільних систем безпеки. Якщо Європейський Союз має намір відігравати ключову роль в управлінні військовими кризами, першою і основною метою ії діяльності має бути ефективне забезпечення виживання і консолідації вразливих держав, а на другому етапі - формування високих стандартів державного управління.

Головним завданням державного управління в Україні $\epsilon$ досягнення ефективності правоохоронної діяльності та високого рівня ефективності та функціонування органів, 
Andrzej Demkowicz

відповідальних за внутрішню безпеку та оборону. Країни, які прагнуть вступити в західноєвропейську політичну систему надійним шляхом, змінять свою нинішню модель функціонування, що не завжди відповідає демократичній i прозорій моделі країн-членів Європейського Союзу. Потенціал втрати російського впливу в Чорноморському регіоні стимулював зусилля СС до формування всіх сфер стратегічної політики безпеки. Операційна співпраця з $€ С$ повинна продовжуватися такими ініціативами, як Бойові групи $€ C$, оскільки це $\epsilon$ важливим елементом, який сприятиме глибшій інтеграції з СС і навіть 3 НАТО в майбутньому. Основною умовою збереження стабільності регіону є послідовний і загальний спосіб дії державчленів ЄС у відносинах 3 Російською Федерацією. Таким чином, шлях до ефективності Європейського Союзу полягає в його безумовній єдності у веденні зовнішньої політики, особливо у сфері безпеки.

Ключові слова: Європейський Союз; Україна; військова криза; СПБО. 